\title{
BRPKM
}

Buletin Riset Psikologi dan Kesehatan Mental

http://e-journal.unair.ac.id/index.php/BRPKM

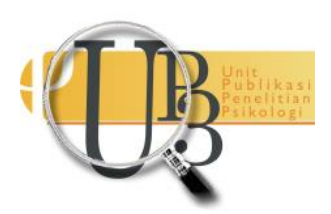

ARTIKEL PENELITIAN

\section{Pengaruh Self-Efficacy terhadap Stres Akademik Mahasiswa dalam Pembelajaran Jarak Jauh Selama Pandemi Covid-19}

\author{
GALUH ARIVIA NASTITI PUTRI \& ATIKA DIAN ARIANA* \\ Departemen Psikologi Klinis dan Kesehatan Mental, Fakultas Psikologi Universitas Airlangga
}

\begin{abstract}
ABSTRAK
Pembelajaran jarak jauh selama pandemi Covid-19 memiliki beberapa kelebihan dan kendala. Kendalakendala ini kemudian menjadi stressor yang menyebabkan stres akademik bagi mahasiswa sehingga diperlukan keyakinan-keyakinan (self-efficacy) dalam diri setiap individu agar mampu menghadapi dan menyelesaikan segala tuntutan-tuntutan tersebut. Penelitian ini bertujuan untuk mengetahui pengaruh self-efficacy terhadap stres akademik mahasiswa dalam pembelajaran jarak jauh selama pandemi Covid19. Penelitian ini dilakukan pada 252 mahasiswa di Indonesia dengan usia 18-21 tahun yang sedang melakukan pembelajaran jarak jauh selama pandemi Covid-19. Alat pengumpul data berupa kuesioner adaptasi Student-Life Stress Inventory dan General Self-efficacy (GSE). Analisis data dalam penelitian ini menggunakan teknik uji regresi linear sederhana. Hasil penelitian ini menunjukan bahwa self-efficacy berpengaruh terhadap stres akademik pada mahasiswa $(\mathrm{R}=0,169 ; \mathrm{p}=0,000)$. Hal ini menandakan bahwa self-efficacy memiliki pengaruh yang signifikan terhadap stres akademik mahasiswa di Indonesia.
\end{abstract}

Kata kunci: mahasiswa, self-efficacy, stres akademik,

\begin{abstract}
Distance learning during the Covid-19 pandemic has several advantages and disadvantages. These constraints become stressors that cause academic stress for students. Self-efficacy is needed so that students are able to manage stressors. This study aims to determine the effect of self-efficacy on student academic stress in distance learning during the Covid-19 pandemic. Total number of participants is 252 students in Indonesia aged 18-21 years who were doing distance learning during the Covid-19 pandemic. Instruments used were the Student-Life Stress Inventory and General Self-efficacy (GSE). Data was analyzed with the simple linear regression. The result of this study indicates that self-efficacy has a significant effect on academic stress of students $(R=0,169 ; p=0.000)$. This indicates that selfefficacy has a significant effect on student academic stress in Indonesia.
\end{abstract}

Keywords: academic stress, self-efficacy, students

Buletin Penelitian Psikologi dan Kesehatan Mental (BRPKM), 2021, Vol. 1(1), 104-111

*Alamat korespondensi: Fakultas Psikologi Universitas Airlangga, Kampus B Universitas Airlangga Jalan Airlangga 4-6 Surabaya 60286.Surel: atika.ariana@psikologi.unair.ac.id

Naskah ini merupakan naskah dengan akses terbuka di bawah ketentuan the Creative Common Attribution License (CC-BY-4.0) (http://creativecommons.org/licenses/by/4.0), sehingga penggunaan, distribusi, reproduksi dalam media apapun atas artikel ini tidak dibatasi, selama sumber aslinya disitir dengan baik. 


\section{PENDAHULUAN}

Pandemi virus Covid-19 yang telah melanda 215 negara di dunia memberikan tantangan tersendiri terutama dalam bidang pendidikan, khususnya perguruan tinggi. Demi mencegah persebaran virus Covid-19, pemerintah telah melarang untuk berkerumunan, pembatasan sosial (social distancing) dan menjaga jarak fisik (physical distancing), memakai masker dan selalu mencuci tangan. Melalui surat edaran Kemendikbud Dikti No. 1 tahun 2020, Kementerian Pendidikan dan Kebudayaan Pemerintah telah melarang perguruan tinggi untuk melaksanakan perkuliahan tatap muka (konvensional) dan memerintahkan untuk menyelenggarakan perkuliahan atau pembelajaran secara daring atau online (Firman \& Rahman, 2020).

Hasibuan dan kawan kawan dalam (Malyana, 2020) menjelaskan pembelajaran jarak jauh atau daring merupakan metode pembelajaran yang menggunakan metode interaktif berbasis internet dan Learning Manajemen System (LMS). Beberapa strategi pembelajaran secara daring yang diterapkan di perguruan tinggi diantaranya adalah pertemuan virtual melalui Zoom atau Google Meet, webinar, dan seluruh kegiatan yang dilakukan dengan menggunakan jaringan internet.

Penggunaan platform pembelajaran daring memiliki beberapa keunggulan yaitu penyebaran pengetahuan yang praktis, bermanfaat bagi individu untuk belajar dan mendapatkan kredensial tetapi tidak menggantikannya secara tatap muka dalam belajar dan mengajar (Shukla, Dosaya, Nirban, \& Vavilala, 2020). Demi kelangsungan pembelajaran selama pandemi virus Covid-19 teknologi ini juga dianggap sangat bermanfaat dan membantu para pelajar untuk tetap mendapatkan pembelajaran yang layak sesuai perencanaan seperti sebelum terjadinya pandemi (Pakpahan \& Fitriani, 2020) . Penelitian lain juga mengatakan bahwa pembelajaran online jarak jauh memiliki waktu yang yang tidak terbatas, banyaknya waktu luang untuk keluarga, lebih menghemat biaya dalam hal transportasi, dan menumbuhkan kemandirian belajar pada pelajar (Handayani, 2020). Namun demikian, penerapan pembelajaran secara daring memiliki beberapa kendala di beberapa negara termasuk Indonesia. Pada daerah tertentu, pembelajaran secara online sulit untuk dilakukan karena jaringan yang kurang memadai (Hastini , Fahmi, \& Lukito, 2020). Pengeluaran biaya tambahan untuk membeli kuota menjadi masalah bagi beberapa orang yang mengalami kendala finansial (Morgan, 2020) dan tidak semua pengajar dapat menyampaikan materi pembelajaran dengan optimal melalui sistem online ini (Morgan, 2020). Kendala-kendala tersebut dapat menyebabkan stressor yang menimbulkan stres akademik pada mahasiswa.

Lazarus dan Folkman dalam (Gadzella, 1994) menjelaskan stres yang dialami seseorang bukan hanya pada situasi atau pada seseorang, tetapi dalam transaksi diantara keduanya (situasi dan juga individu) tergantung pada bagaimana seseorang tersebut menilai situasi dan beradaptasi dengannya (Gadzella, 1994). Penelitian Livana, Mubin dan Bastomi (2020) terkait penyebab stres mahasiswa selama pandemi Covid-19 menunjukan terdapat 7 tema terkait penyebab stres yang dialami oleh mahasiswa selama pandemi virus Covid-19. Salah satu tema yang paling banyak dipilih oleh responden untuk mengungkapkan penyebab stres yang dialami selama pandemi adalah tugas perkuliahan (70\%), kemudian diikuti oleh proses pembelajaran daring yang membosankan $(55,8 \%)$ dan tidak dapat mengikuti pembelajaran daring/online karena kuota internet yang terbatas (37, 4\%). Penelitian Maia dan kawan-kawan dalam (Hasanah, Ludiana, Immawati, \& Livana , 2020) menunjukan bahwa mahasiswa yang dievaluasi selama pandemi Covid-19 menunjukan tingkat kecemasan, depresi, dan stres yang jauh lebih tinggi, dibandingkan dengan sebelum adanya pandemi. Depresi pada mahasiswa 
dapat menimbulkan manifestasi psikomotor berupa semangat, keadaan gairah dan produktivitas kerja yang menurun, serta daya pikir dan konsentrasi yang melambat (Livana, Mubin, \& Basthomi, 2020).

Govaerst dan Gregoire dalam (Suwartika, Nurdin, \& Ruhmadi, 2014) menyatakan bahwa konteks terdekat dari kehidupan individu akan menyebabkan stres paling tinggi serta mengganggu kehidupannya. Perkuliahan merupakan konteks yang paling dekat dengan mahasiswa. Mahasiswa selain dituntut untuk menyelesaikan tuntutan-tuntutan akademik mereka, sebagai remaja akhir (18-21 tahun) mereka juga lebih memiliki tugas-tugas perkembangan yang harus dipenuhi (Santrock, 2007; Black, 2010). Tuntutan-tuntutan akademik yang yang harus diselesaikan oleh mahasiswa dapat menyebabkan mereka mengalami stres akademik. Menurut Gadzella dan Masten dalam (Aula \& Leonardi, 2017) menjelaskan bahwa stres akademik adalah persepsi individu terhadap stressor akademik dan bagaimana reaksi individu terhadap stressor tersebut, reaksi yang ditimbulkan terdiri dari reaksi fisik, emosi, perilaku dan kognitif. Jika dikaitkan dengan keadaan mahasiswa yang sedang mengalami pembelajaran online sekarang ini, stressor akademik berupa jaringan yang kurang memadai, pengeluaran biaya tambahan untuk membeli kuota, tidak semua pengajar dapat menyampaikan materi pembelajaran dengan optimal, banyaknya tugas, tidak memahami materi, sulit mengatur waktu, mudah terdistraksi, fasilitas terbatas.

Para peneliti telah mengusulkan bahwa derajat dan status stres akademik tidak ditampilkan secara seragam di semua mahasiswa tetapi cenderung ditentukan menurut perbedaan individu yang dapat disebut sebagai sumber daya pribadi (Jung, Kim, Ma, \& Seo, 2015). Sumber daya pribadi adalah "kualitas yang mampu mempengaruhi efek stres pada kesehatan mental orang" (Jung, Kim, Ma, \& Seo, 2015), di antara sumber daya pribadi, self-efficacy telah mendapat perhatian yang semakin meningkat dari para peneliti sebagai salah satu faktor individu yang efektif untuk mengatur efek stres akademik pada hasil stres (Jung, Kim, Ma, \& Seo, 2015). Bandura (1997) menjelaskan self-efficacy merupakan keyakinan individu terkait kemampuannya dalam melakukan tugas atau tindakan yang diperlukan untuk mencapai hasil tertentu.

Lazarus dan Folkman dalam (Zajacova, Lyinch, \& Espenshade, 2005) menjelaskan self-efficacy dan stres adalah kedua konsep yang saling terkait erat. Keyakinan pribadi seperti self-efficacy sangat penting dalam mengevaluasi tuntutan dari lingkungan. Setiap tuntutan eksternal akan dievaluasi sebagai ancaman atau tantangan, dan orang-orang dengan self-efficacy diri yang tinggi lebih cenderung untuk mengevaluasinya sebagai sebuah tantangan (Zajacova, Lyinch, \& Espenshade, 2005). Sejauh mana seseorang tersebut merasa percaya diri tentang kompetensinya untuk menangani situasi tertentu mempengaruhi apakah tugas yang diberikan dianggap sebagai ancaman atau justru tantangan (Bandura, 1997). Keterkaitan antara self-efficacy dan stres akademik pada mahasiswa selama pandemi Covid-19 ini sebelumnya sudah pernah dikaji oleh Utami, Rufaidah, dan Nisa (2020). Mereka menemukan bahwa variabel self-efficacy dan stres akademik menunjukan kontribusi yang bersifat negatif yang memiliki arti bahwa ketika self-efficacy tersebut meningkat maka akan terjadi penurunan stres akademik. Penelitian yang dilakukan oleh Siregar dan Putri (2019) dan Sagita, Daharnis, dan Syahniar (2017) juga menunjukan korelasi yang negatif antara variabel stres akademik dan variabel self-efficacy. Hasil-hasil penelitian tersebut semakin menguatkan bahwa terdapat hubungan yang erat antara self-efficacy dan stres akademik.

Berdasarkan penjelasan tersebut, penulis melakukan penelitian ini untuk mengetahui pengaruh selfefficacy terhadap stres akademik pada mahasiswa yang sedang melakukan pembelajaran jarak jauh selama pandemi Covid-19. Pertanyaan dalam penelitian ini berfokus pada seberapa besar pengaruh self- 
efficacy terhadap stres akademik pada mahasiswa yang sedang melakukan pembelajaran jarak jauh selama pandemi Covid-19.

\section{Desain Penelitian}

\section{METODE}

Desain penelitian ini adalah penelitian kuantitatif dengan teknik pengumpulan data berupa survei, yaitu penelitian yang dilaksanakan tanpa melakukan manipulasi situasi atau kondisi. Penelitian dengan teknik survei melibatkan orang-orang untuk mengisi kuesioner tertulis atau menjawab pertanyaan dalam sebuah wawancara (Neuman, 2007). Metode survei ini menjadi alternatif yang paling murah mengingat pengambilan data dilakukan pada saat pandemi.

\section{Partisipan}

Partisipan dalam penelitian ini merupakan mahasiswa di Indonesia yang memiliki rentang usia 18-21 tahun dan sedang melakukan pembelajaran jarak jauh selama pandemi Covid-19. Proses pemilihan subjek menggunakan teknik simple random sampling. Teknik ini memungkinkan distribusi menjadi normal dengan semakin banyak partisipan yang berpartisipasi dan serupa dengan populasi sehingga kemungkinan untuk tidak akurat dapat diprediksi (Neuman, 2007). Sebelum mengisi kuesioner penelitian terlebih dahulu partisipan diberikan lembar informed consent sebagai bukti kesediaan untuk sebagai partisipan penelitian.

Total partisipan dalam penelitian ini adalah 252 orang $\left(M_{\text {usia }}=20,16 ; S D_{\text {usia }}=0,96 ; 81,3\right.$ persen perempuan). Mayoritas usia partisipan paling banyak 21 tahun (48\%), kemudian diikuti mahasiswa paling banyak pada semester 7 (43\%).

\section{Pengukuran}

Pengukuran self-efficacy menggunakan General Self-Efficacy, yang terdiri dari 10 item dengan pilihan 4 jawaban (1= "sama sekali tidak benar", 2= "hampir tidak benar", 3= "cukup benar", 4= "benar sekali"). General Self-Efficacy mempunyai reliabilitas yang sangat baik $(\alpha=0,861)$. Pengukuran stres akademik menggunakan Student-life Stress Inventory, yang terdiri dari 51 item dengan pilihan jawaban (1= "tidak pernah", 2= "jarang", 3= "kadang-kadang", 4= "sering", 5= "hampir setiap waktu"). Reliabilitas Studentlife Stress Inventory juga tergolong sangat baik $(0,936)$.

Kedua instrumen telah melalui uji validitas menggunakan validitas konten dan validitas konstruk. Skala Student-life Stress Inventory diterjemahkan dari Bahasa inggris ke Bahasa Indonesia. Hasil terjemahan tersebut kemudian dilihat kesesuaian terjemahannya oleh pakar. Hasil expert judgment menunjukan terdapat 1 item yang tidak dimengerti sehingga item tersebut diperbaiki. Item yang diperbaiki adalah item no.43 yang semula berbunyi "menggunakan mekanisme pertahanan diri" menjadi "menggunakan mekanisme pertahanan diri (misalnya mencari alasan, menyembunyikan perasaan yang sesungguhnya, menyangkal atau mengelak)". Hasil Confirmatory Factor Analysis (CFA) pada skala General Self-Efficacy menunjukan bahwa item-item instrumen ini secara signifikan bersifat unidimensional yang hanya mengukur self-efficacy secara menyeluruh dan mendukung model satu faktor yang diteorikan (Novrianto, Marettih, \& Wahyudi, 2019). 


\section{Analisis Data}

Uji asumsi parametrik pada data menunjukkan adanya sebaran data yang normal dan linear. Uji homoskedastisitas berdasarkan scatter plots regression menunjukan hasil penyebaran data secara acak dan tidak memiliki suatu pola tertentu sehingga tidak terjadi asumsi heteroskedastisitas dan data dalam penelitian ini memenuhi syarat untuk melakukan uji regresi. Dengan demikian data memenuhi asumsi parametrik dan dianalisis menggunakan teknik analisis regresi linier sederhana. Analisis statistik dilakukan dengan menggunakan software perhitungan statistik SPSS versi 22.0 for Windows.

\section{HASIL PENELITIAN}

Hasil analisis deskriptif menunjukan mayoritas partisipan mengalami stres akademik kategori rendah yakni sebanyak 110 orang $(43,7 \%)$, kategori sedang sebanyak 89 orang $(35,3 \%)$ dan pada kategori tinggi sebanyak 53 orang (21\%). Kategorisasi stres akademik ini ditentukan menggunakan norma dari Gadzella (2004, dalam Sirina, 2012). Hasil penelitian juga menunjukan mayoritas partisipan memiliki self-efficacy kategori tinggi yakni sebanyak 135 orang (53,6\%), kategori sedang sebesar 112 orang $(44,4 \%)$ dan kategori rendah sebanyak 5 orang $(2 \%)$. Kategorisasi pada variabel self-efficacy ini menggunakan rumus penormaan dari Azwar (2012).

Hasil analisis regresi linier sederhana menunjukan self-efficacy berkorelasi negatif dan cenderung lemah dengan stress akademik mahasiswa dalam pembelajaran jarak jauh selama pandemi Covid-19 (F $\left.(1,250)=7.318 ; \mathrm{p}<0,001 ; \mathrm{R}^{2}=0,28\right)$. Variabel self-efficacy dapat memprediksi $2,8 \%$ dari variabel stres akademik.

\section{DISKUSI}

Tujuan penelitian ini adalah untuk mengetahui pengaruh self-efficacy terhadap stres akademik mahasiswa dalam pembelajaran jarak jauh selama pandemi Covid-19. Hasil analisis data menunjukan bahwa self-efficacy memiliki pengaruh yang signifikan terhadap stres akademik sehingga dapat disimpulkan bahwa Ha diterima, meskipun pengaruh yang dihasilkan cenderung lemah. Kontribusi yang ditunjukan oleh self-efficacy dalam penelitian ini bersifat negatif yang berarti semakin tinggi self-efficacy maka semakin rendah stres akademik individu.

Hasil penelitian ini selaras dengan hasil penelitian-penelitian terdahulu (Sagita, Daharnis, \& Syahniar, 2017; Siregar \& Putri, 2019; Utami, Rufaidah, \& Nisa, 2020). Mahasiswa yang memiliki self-efficacy yang rendah cenderung malas, cemas dan tidak percaya diri dalam mengerjakan tugas perkuliahan sehingga berada dalam derajat stres akademik yang tinggi (Sagita, Daharnis, \& Syahniar, 2017). Sebaliknya, mahasiswa yang memiliki self-efficacy yang tinggi akan cenderung berada pada derajat stres akademik yang rendah (Siregar \& Putri, 2019). Selanjutnya, self-efficacy diketahui berpengaruh secara signifikan terhadap stres akademik mahasiswa selama pandemi Covid-19 (Utami, Rufaidah, \& Nisa, 2020).

Penelitian sebelumnya oleh Utami, Rufaidah, dan Nisa (2020) menunjukan bahwa self-efficacy menyumbang sebanyak $22 \%$ faktor untuk memprediksi stress akademik, namun dalam penelitian ini self-efficacy menunjukan pengaruh yang cenderung lemah yakni 2,8\% faktor untuk memprediksi stress akademik. adapun 97,2\% dibentuk oleh variabel lainnya yang tidak diteliti oleh peneliti melalui penelitian ini. Lemahnya kontribusi self-efficacy dalam penelitian ini karena dibanding penelitian sebelumnya yang partisipannya sedikit, dalam penelitian ini variasi partisipan lebih banyak sehingga variasi jawaban yang dihasilkan lebih banyak, kemudian beberapa variabel diluar penelitian yang 
kemungkinan mempengaruhi stres akademik adalah seperti faktor-faktor seperti kepribadian hardiness, optimism, motivasi berprestasi, prokrastinasi dan dukungan sosial orang tua.

Goff (dalam Dini, Fitriyasari, \& Asmoro, 2020) menyatakan bahwa stres akademik yang meningkat dapat menurunkan kemampuan akademik yang akan berpengaruh pada indeks prestasi individu. Beban kerja dan stres yang tinggi memiliki pengaruh langsung pada kinerja akademik dan kesejahteraan mahasiswa. Stres akademik mahasiswa dapat bersumber dari kehidupan akademiknya, terutama tekanan eksternal dan harapan yang dipaksakan sendiri, beban akademik, stres emosional, keluarga, teman penyesuaian sosial dan tekanan keuangan (Kariv \& Heiman, 2005). Sementara itu, menurut Bandura (dalam Utami, Rufaidah, \& Nisa, 2020) self-efficacy merupakan penentu utama dalam berlangsungnya suatu perilaku. Penentu dalam berlangsungnya suatu perilaku dalam pernyataan ini adalah ketika seseorang merasa dirinya yakin akan suatu hal, dalam hal ini adalah mengerjakan suatu tugas maka individu tersebut akan memiliki rasa kepercayaan diri dalam dirinya untuk mengerjakan tugas tersebut. Namun hal sebaliknya akan terjadi jika pada diri seseorang tersebut tertanam rasa tidak yakin maka individu yang bersangkutan akan terhambat bahkan mungkin akan tidak mampu dalam mengerjakan tugas yang telah diberikan kepadanya atau ketika sesorang merasa yakin jika dirinya mampu menyelesaikan suatu tugas yang diberikan, maka akan muncul optimisme. Hal itu tentu saja akan berbeda pada individu yang kurang atau bahkan tidak memiliki keyakinan (self-efficacy) pada dirinya dalam mengerjakan suatu tugas, sehingga dalam dirinya muncul perasaan yang kurang menyenangkan dan dapat menjadi penyebab munculnya stres akademik sebab ini terkait tugas yang dibebankan pada dirinya, semisal tugas perkuliahan (Utami, Rufaidah, \& Nisa, 2020).

Ahmad dan Safarian dalam (dalam Utami, Rufaidah, \& Nisa, 2020) menjelaskan bahwa individu dengan self-efficacy tinggi mempunyai penilaian diri yang positif, mampu meyakinkan orang lain, mampu menyusun situasi dengan cara-cara yang membawa kesuksesan, dan dapat menghindari kegagalan. Selfefficacy yang tinggi mendorong individu untuk mengukur keberhasilan berdasarkan evaluasi diri dan bukan perbandingan dengan capaian orang lain. Hal inilah yang menekan resiko stres. Pada akhirnya, keyakinan diri menentukan yang sikap dalam mengelola tugas. Ketika individu memiliki persepsi bahwa tugas tersebut susah, kemungkinan besar stres akademik akan terjadi dan begitu pula sebaliknya (Utami, Rufaidah, \& Nisa, 2020).

\section{SIMPULAN}

Berdasarkan hasil penelitian dapat disimpulkan bahwa self-efficacy memiliki pengaruh yang signifikan terhadap stres akademik pada mahasiswa yang sedang melakukan pembelajaran jarak jauh selama pandemi Covid-19. Kontribusi yang ditunjukan oleh self-efficacy terhadap stres akademik menunjukan hasil yang bersifat negatif, dalam artian ketika self-efficacy meningkat maka stres akademik akan menurun. Hasil yang ditunjukan dalam penelitian ini semakin menguatkan hasil-hasil penelitian terdahulu terkait self-efficacy berhubungan erat dengan stres akademik.

Saran bagi mahasiswa untuk mereduksi stres akademik dapat dilakukan dengan meningkatkan selfefficacy dengan cara mengenali diri sendiri, menetapkan tujuan dan rencana, serta fokus pada evaluasi diri, dibandingkan dengan membandingkan diri dengan capaian orang lain. Kemudian saran bagi penelitian selanjutnya untuk mempertimbangkan faktor-faktor lain yang dapat mempengaruhi stress akademik selain self-efficacy dan menambah variasi sampel. Selanjutnya, saran bagi perguruan tinggi agar mengadakan monitoring berkala atas kemajuan akademik mahasiswa serta mengembangkan atmosfir akademik yang meningkatkan keyakinan diri setiap sivitas akademika. 


\section{UCAPAN TERIMAKASIH}

Terima kasih saya ucapkan kepada Allah SWT, keluarga, dan teman-teman dan pihak-pihak terkait yang telah banyak membantu dan mendukung penulis dalam proses penelitian.

\section{DEKLARASI POTENSI TERJADINYA KONFLIK KEPENTINGAN}

Galuh Arivia Nastiti Putri dan Atika Dian Ariana tidak bekerja, menjadi konsultan, memiliki saham, atau menerima dana dari perusahaan atau organisasi manapun yang mungkin akan mengambil untung dari diterbitkannya naskah ini.

\section{PUSTAKA ACUAN}

Aula, N. A. (2017). Hubungan Antara Academic Stress Dengan Problematic Internet Use Pada Mahasiswa Di Surabaya. Skripsi. Surabaya: Universitas Airlangga.

Aula, N. A., \& Leonardi, T. (2017). Hubungan Antara Academic Stress dengan Problematic Internet Use Pada Mahasiswa di Surabaya. Jurnal Psikologi Pendidikan dan Perkembangan, 6, 67-76.

Azwar, S. ( 2012). Reliabilitas dan validitas. Yogyakarta: Pustaka Belajar.

Bandura, A. (1997). Self efficacy: the exercise of control. New York: W.H Freeman and Company.

Black, A. S. (2010). "Halfway between somewhere and nothing": A exploration of the quarter-life crisis and life satisfaction among graduate students. University of Arkansas.

Dini, M. P., Fitriyasari, R., \& Asmoro, C. P. (2020). The Relationship Between Self-Efficacy and Academic Workloads With Stress Of Nursing Internship: Literature Review. Psychiatry Nursing Journal, 2 (2).

Firman, \& Rahman, S. R. (2020). Pembelajaran Online di Tengah Pandemi Covid-19. Indonesian Journal of Educational Science (IJES), 2 (2).

Gadzella, B. M. (1994). Student-Life Stress Inventory: Identification Of and Reactions To Stressors. Psychological Report, 74, 395-402.

Handayani, L. (2020). Keuntungan, Kendala dan Solusi Pembelajaran Online Selama Pandemi Covid-19 : Studi Ekploratif di SMPN 3 Bae Kudus. Journal Indsustrial Enginering \& Management Research (JIEMAR), 1(2).

Hasanah, U., Ludiana, Immawati, \& Livana , P. (2020). Gambaran Psikologis Mahasiswa Dalam Proses Pembelajaran Selama Pandemi Covid-19. Jurnal Keperawatan Jiwa, 8 (3), 299-306.

Hastini , L. Y., Fahmi, R., \& Lukito, H. (2020). Apakah Pembelajaran Menggunakan Teknologi dapat Meningkatkan Literasi Manusia pada Generasi Z di Indonesia? Jurnal Manajemen Informatika, 10 (1).

Jung, I., Kim, J., Ma, Y., \& Seo, C. (2015). Mediating Effect of Academic Self-Efficacy on the Relationship between Academic Stress and Academic Burnout in Chinese Adolescents. International Journal of Human Ecology, 16(2), 63-77.

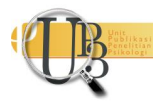


Kariv, D., \& Heiman, T. (2005). Task-oriented versus emotion-oriented coping strategies: The case of college students. College Students Journa, 39 (1), 72-89.

Livana, P., Mubin, M. F., \& Basthomi, Y. (2020). "Tugas Pembelajaran" Penyebab Stres Mahasiswa Selama Pandemi COVID-19. Jurnal Ilmu Keperawatan Jiwa, 3 (2), 203-208.

Malyana, A. (2020). Pelaksanaan Pembelajaran Daring dan Luring dengan Metode Bimbingan Berkelanjutan pada Guru Sekolah Dasar di Teluk Betung Utara Bandar Lampung. Pedagogia: Jurnal Ilmiah Pendidikan Dasar Indonesia, 2(1), 67-76.

Morgan, H. (2020). Best Practices for Implementing Remote Learning during a Pandemic. The Clearing House: A Journal of Educational Strategies, Issues and Ideas, 93 (3), 134-140.

Neuman. (2007). Basic of social research: Qualitative and quantitative approaches. Boston: Pearson Education Inc.

Novrianto, R., Marettih, A. K., \& Wahyudi, H. (2019, Mei 17). Validitas Konstruk Instrumen General Self Efficacy Scale Versi Indonesia. http://dx.doi.org/10.24014/ jp.v14i2.6943

Pakpahan, R., \& Fitriani, Y. (2020). Analisa Pemanfaatan Teknologi Informasi dalam Pembelajaran Jarak Jauh di Tengah Pandemi Virus Corona COVID-19. Journal of Information System, Applied, Management, Accounting and Researh, 4 (2).

Sagita, D. D., Daharnis, \& Syahniar. (2017). Hubungan Self-efficacy, Motivasi Berprestasi, Prokrastinasi Akademik Dan Stres Akademik Mahasiswa. Jurnal Bikotetik, 1 (2), 37-72.

Santrock, J. W. (2007). Remaja, jilid 2 edisi kesebelas. Jakarta: Erlangga.

Shukla, T., Dosaya, D., Nirban , V. S., \& Vavilala, M. P. (2020). Factors Extraction of Effective TeachingLearning in Online and Conventional Classrooms. International Journal of Information and Education Technology, vol. 10, No. 6.

Siregar, I. K., \& Putri, S. R. (2019). Hubungan Self-Efficacy dan Stres Akademik Mahasiswa. Consilium: Berkala Kajian KonselingDDan Ilmu Keagamaan, 91-95.

Siregar, I. K., \& Putri, S. R. (2019). Hubungan Self-Efficacy dan Stres Akademik Mahasiswa. Consilium : Berkala Kajian Konseling Dan Ilmu Keagamaan, 6(2), 91-95.

Suwartika, I., Nurdin, A., \& Ruhmadi, E. (2014). Analisis Faktor Yang Berhubungan Dengan Tingkat Stres Akademik Mahasiswa Reguler Program Studi D III Keperawatan Cirebon Poltekkes Kemenkes Tasikmalaya. Jurnal Keperawatan Soedirman, 9(3).

Utami, S., Rufaidah, A., \& Nisa, A. (2020). Kontribusi self-efficacy terhadap stres akademik mahasiswa selama pandemi Covid-19 periode April-Mei 2020 . TERAPUTIK Jurnal Bimbingan dan Konseling, 4 (1), 20-27.

Zajacova, A., Lyinch, S. M., \& Espenshade, T. J. (2005). Self-efficacy, Stres, And Academic Succes In Collage. Research in Higher Education, 46(6).

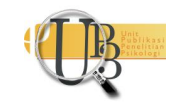

